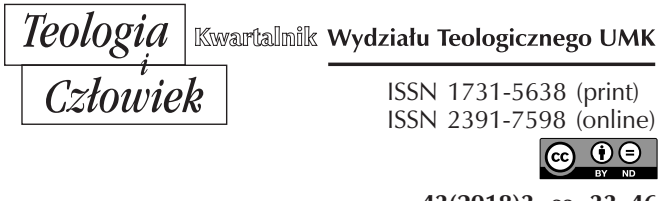

43(2018)3, ss. $33-46$

KS. TOMASZ DUTKIEWICZ WYDZIAŁ TEOLOGICZNY UNIWERSYTETU MIKOŁAJA KOPERNIKA W TORUNIU TOMASZ.DUTKIEWICZ@OP.PL

\title{
TEZA O AKSJOLOGICZNEJ NEUTRALNOŚCI UCZUĆ A KATOLICKA NAUKA O ICH ROLI W ŻYCIU MORALNYM CZŁOWIEKA. PRÓBA ANTROPOLOGICZNO-ETYCZNEJ ANALIZY PROBLEMU
}

DOI: http://dx.doi.org/10.12775/TiCz.2018.025

Streszczenie. W wypowiedziach i publikacjach niektórych autorów, także katolickich, pojawia się lansowana w sposób dobitny teza, w myśl której ludzkie uczucia nie podlegają ocenie moralnej. Wydaje się, że powoływanie się w jej uzasadnieniu na myśl św. Tomasza z Akwinu, czy też na Katechizm Kościoła Katolickiego, świadczyć może co najmniej o wyjątkowo nieuważnej lekturze tych tekstów, z którymi teza ta nie daje się pogodzić.

Celem opracowania jest przedstawienie antropologiczno-etycznych uwarunkowań problemu, w szczególności zaś wskazanie na przyjmowanie przez niektórych teologów antropologicznych podstaw sprzecznych z nauka objawioną, zaczerpniętych z wpływowych koncepcji psychologicznych oraz na nieuwzględnianie różnorodności przejawów życia uczuciowego, skutkujące brakiem precyzji sformułowań w odniesieniu do ich moralnej oceny.

Słowa kluczowe: uczucia; wartość moralna uczuć; psychologizm.

Abstract. Thesis on Axiological Neutrality of Emotions and Catholic Teaching on Their Role in Moral Life. The Attempt at Anthropological and Ethical Analysis of the problem. In discussions and publications of some authors, also Catholic ones, there 
appears a popular thesis suggesting that human emotions are not subject to moral judgment. It seems that the reference to the thought of St. Thomas Aquinas or the Catechism of the Catholic Church to prove this point may be a sign of, at least, a careless reading of these texts as this thesis is absolutely incompatible with them.

The aim of this article is to present anthropological and ethical determinants of the problem, in particular to indicate that the adoption by some theologians anthropological foundations is contrary to the Revelation and originates from influential psychological concepts and the ignorance of various manifestations of emotional life resulting from the lack of precision in formulating their moral evaluation.

Keywords: emotions; moral value of emotions; psychologism.

\section{WSTĘP}

Katechizm Kościoła Katolickiego w trzeciej swojej części, poświęconej zagadnieniom dotyczącym życia chrześcijańskiego, odrębny artykuł poświęca moralności uczuć ${ }^{1}$ Znaleźć w nim możemy stwierdzenie, w myśl którego „uczucia same w sobie nie są ani dobre ani złe”2. Zaraz jednak, w następnym zdaniu, czytamy, że „nabierają one wartości moralnej w takiej mierze, w jakiej faktycznie zależą od rozumu i od woli”3. Czy zatem lansowanie samej tezy, głoszącej że uczucia nie są ani dobre ani złe, nie pozostaje klasycznym przykładem głoszenia półprawdy, która uzurpując sobie pretensję do bycia „całą prawdą”, staje się w istocie fałszem? Czy w świetle katechizmowego stwierdzenia, stanowiącego cytat z Sumy Teologicznej św. Tomasza z Akwinu, zgodnie z którym uczucia nazywane są dobrowolnymi „albo dlatego, że nakazuje je wola, albo dlatego, że ich nie zabrania", nie należy uznać, że odpowiedzialność moralna za poruszenia ludzkiej zmysłowości rozpoczyna się wcześniej, zanim jeszcze doprowadzą one do zajęcia określonej postawy, czy też podjęcia pod ich wpływem konkretnych działań?

1 Zob. artykuł piąty, zatytułowany „Moralność uczuć”, obejmujący numery $1762-1775$.

2 KKK 1767.

3 KKK 1767.

${ }^{4}$ KKK 1767; Tomasz z Akwinu, Suma teologiczna, I-II, 24, 1. 
Wydaje się, że podejmowanie tematyki związanej z moralnym wymiarem życia emocjonalnego wymaga należytej kompetencji oraz szczególnej uwagi, tak by „radosnym odkryciem” po przeczytanej lekturze czy wysłuchanych rekolekcjach nie pozostało fałszywe przeświadczenie o braku konieczności ascezy w odniesieniu do tej - jakże ważnej - dziedziny ludzkiej osobowości. Tego rodzaju podejście stanowiłoby z całą pewnością sprzeniewierzenie się tej wrażliwości moralnej, której uczył Zbawiciel, wskazując na konieczność pogłębionej interpretacji przykazań, sięgającej w głąb ludzkiego wnętrza ${ }^{5}$.

W ramach podjętych rozważań będziemy chcieli wskazać na antropologiczno-etyczne uwarunkowania rozbieżności, jaka pojawia się niekiedy pomiędzy oficjalnym nauczaniem Kościoła a niefrasobliwie stawianą przez niektórych katolickich autorów tezą, w myśl której uczucia nie podlegają ocenie moralnej6.

\section{PSYCHOLOGIA W ROLI SŁUŻEBNICY TEOLOGII?}

Wydaje się, że jednym $\mathrm{z}$ takich uwarunkowań może być bezkrytyczne i nieświadome asymilowanie na gruncie teologii koncepcji człowieka, jaką przyjmują twórcy wiodących nurtów psychologicznych, a która pozostaje w sprzeczności zarówno z nadprzyrodzonym Objawieniem, jak i z klasyczną antropologią filozoficzną. Wykorzystując osiągnięcia tychże autorów i nawiązując - w ramach np. formacji duchowej - do wypracowanych przez nich rozwiązań, nie zawsze uwzględnia się fakt, że znakomita większość z nich była ateistami, i to o nastawieniu rewolucyjnym,

${ }^{5}$ Mt 5,21-22. A także sięgającej czasów Platona i Arystotelesa koncepcji cnót moralnych, których zadaniem jest m.in. porządkowanie sfery poruszeń zmysłowych w człowieku.

${ }^{6}$ Np. ks. Krzysztof Grzywocz, ceniony rekolekcjonista, wykładowca teologii duchowości, prowadzący zajęcia w Szkole Formatorek Zakonnych i w Szkole Wychowawców Seminaryjnych, stwierdza kategorycznie: „Uczucia nie podlegają ocenie moralnej. Tak uczył już św. Tomasz z Akwinu i wielu innych, tak też uczy Katechizm Kościoła Katolickiego (zob. nr 1768). Nie ma uczucia - w sensie moralnym - które byłoby negatywne". K. Grzywocz, Uczucia niekochane, Kraków 2008, s. 18. 
zmierzającym do zniszczenia tradycyjnej religii i moralności ${ }^{7}$. Ich sposób rozumienia tego, kim jest człowiek, odbiegał tym samym zasadniczo od personalistycznego ujęcia ludzkiej istoty jako świadomej i wolnej, stworzonej na obraz i podobieństwo Boga, powołanej do świętości.

Teologia jako nauka wiary ukształtowana została w swojej strukturze - o czym przypomina w encyklice Fides et ratio Jan Paweł II - przez podwójną zasadę metodologiczną, obejmującą etap przyswojenia sobie treści objawionych (auditus fidei) oraz etap spekulatywnej refleksji nad nimi (intellectus fidei) . $^{\text {W }}$ prowadzeniu tej refleksji, teologii niezbędne jest instrumentarium, którego sama nie tworzy, ale które wypracowane zostaje wcześniej na gruncie filozofii ${ }^{9}$. Stąd sięgające jeszcze patrystyki, a spopularyzowane w średniowieczu, określenie tej ostatniej mianem ancilla theologiae „służebnicy teologii” ${ }^{10}$. Z punktu widzenia kondycji teologii pozostaje zatem rzeczą ogromnej wagi, by była to filozofia w sposób poprawny odczytująca rzeczywistość, tzn. udzielająca zgodnych ze stanem faktycznym odpowiedzi na pytania o naturę świata, w szczególności zaś o naturę człowieka, jego pochodzenie i ostateczny cel. Teologia - jak podkreśla Jan Paweł II - potrzebuje filozofii „o zasięgu prawdziwie metafizycznym”, która „nie zaprzecza, że możliwe jest poznanie obiektywnie prawdziwe"11.

7 Zob. A. Wasiukiewicz, Niebezpieczna psychologia, Poznań 2017, s. 13. Autorka ujmuje tę kwestię bardziej jeszcze radykalnie, stwierdzając, że „niechęć do religii, zwłaszcza do chrześcijaństwa, cechowała wszystkich liczących się twórców wiodących kierunków psychologicznych. Wśród tzw. ojców założycieli psychologii nie było ani jednego praktykującego katolika. Wszyscy byli ateistami i na ogół wywodzili się z rodzin protestanckich i żydowskich. Ponadto też byli rewolucjonistami, którzy za cel życia postawili sobie walkę $\mathrm{z}$ religią, Kościołem oraz z tradycyjną moralnością".

8 Fides et ratio 65.

9 Teologia katolicka, będąc racjonalizacją wiary objawionej, stanowi naukę pod względem metodologicznym wyjątkową - nadprzyrodzoną w swoich podstawach, lecz naturalną w swojej formie (fundamentaliter supranaturalis sed formaliter naturalis). Jej narodziny jako systematycznie uprawianej dziedziny wiedzy związane są z powstaniem scholastyki. W myśl postulatu, by wiara szukała zrozumienia (fides querens intellectum) postawionego przez jej twórcę, św. Anzelma z Canterbury, zaczęto wówczas stosować racjonalną dialektykę i filozofię w celu wyjaśnienia i uporządkowania prawd wiary. Zob. S. Kamiński, Nauka i metoda. Pojęcie nauki i klasyfikacja nauk, Lublin 1992, s. 315-316.

${ }^{10}$ Więcej na ten temat zob. P. Moskal, Diakonia prawdy i „ancilla theologiae”, w: red. A. Maryniarczyk, Rozum otwarty na wiare, Lublin 2000, s. 107-112.

11 P. Moskal, Diakonia prawdy, s. 82-83. 
W tym samym tonie wypowiada się również papież Benedykt XVI, stwierdzając, że „kiedy podstawy filozofii nie są jasne, teologii zaczyna brakować gruntu pod nogami. Nie wiadomo wtedy, jak dalece człowiek poznaje naprawdę rzeczywistość, a co za tym idzie, jakie są podstawy, na których może się on oprzeć w myśleniu i mówieniu"12.

Pomnikowym wyrazem troski o to, by teologia posiadała na swoje usługi prawdziwą filozofię, stała się słynna encyklika papieża Leona XIII, Aeterni Patris, która jako pierwsza w dziejach Kościoła w całości poświęcona została filozofii. Jej ogłoszenie w roku 1879 miało stanowić - w zamyśle autora - odpowiedź na ówczesne zagrożenia wiary, na które jako skuteczne remedium wskazywał on metodę filozoficzną św. Tomasza, który - jak czytamy w tym dokumencie - „sam jeden zwalczył błędy z wcześniejszych czasów, ale też podał niezwyciężony oręż do zwalczania i zniszczenia tych błędów, które nieprzerwaną zmiennością losów pojawią się dopiero w przyszłości”'13. Papież żywił głębokie przekonanie, że powrót do myśli Akwinaty odnowi teologię i pozwoli przeciwstawić się zagrażającym wierze nurtom II połowy XIX stulecia. Dawał temu wyraz, pisząc, że „przerażone i pokonane jego [św. Tomasza] nauką wszelkie herezje zmieszane i zwyciężone ulegają unicestwieniu, a cała ziemia codziennie uwalnia się od zaraźliwych błędów"14. W rzeczywistości encyklika Aeterni Patris stała się impulsem do wielkiej odnowy tomistycznej, obficie owocującej w kolejnych kilkudziesięciu latach.

Na krótko przed drugą wojną światową pojawił się jednak postulat stworzenia tzw. „nowej teologii”, która miałaby bardziej uwzględnić ludzką tendencję do irracjonalizmu i stać się przez to - według ówczesnych haseł - bardziej „strawną” dla współczesnego człowieka. Według zaproponowanej $\mathrm{w}$ ich myśl wizji, teologia ta miała być programowo mniej scholastyczna, bardziej natomiast biblijno-patrystyczna oraz ukierunkowana praktycznie. Dyskusję, która potoczyła się w tej sprawie w latach powojennych (1946-1950), zahamował pierwotnie zarzut, że podejście takie doprowadzi do relatywizmu ${ }^{15}$. Jej kontynuacja oraz próba realizacji

12 Benedykt XVI, Jedność myśli i ducha Jana Pawła II, w: Jan Paweł II - mój umiłowany poprzednik, tłum. R. Łobko, Częstochowa 2007, s. 20-21.

13 Aeterni Patris 18.

14 Tamże, 21. Leon XIII przytacza te słowa za bullą Piusa V Verbo mirabilis.

${ }^{15} \mathrm{Na}$ uwagę zasługuje w tym kontekście stanowisko Piusa XII, który w wydanej 
stawianych wcześniej postulatów nastąpiła po Soborze Watykańskim II. Mimo pierwotnego entuzjazmu, czas miał jednak pokazać, że samo odrzucenie scholastycznej filozofii nie odnowiło teologii, generując problem, czym i jak zastąpić można by posługiwanie się filozofią klasyczną ${ }^{16}$.

Wydaje się rzeczą oczywistą, że wykorzystywanie w celu racjonalizacji treści objawionych rozwiązań filozoficznych, które na poziomie kwestii fundamentalnych pozostają w sprzeczności z wiarą chrześcijańską, nie może dobrze przysłużyć się teologii. Stąd też Jan Paweł II, podobnie jak jego wielki, dziewiętnastowieczny Poprzednik podejmuje apel, by wrócić do metody filozoficznej św. Tomasza z Akwinu, którego w Fides et ratio ukazuje jako „mistrza sztuki myślenia i wzór właściwego uprawiania teologii"17. Podobnie jak Leon XIII, wskazuje on również szereg współczesnych sobie zagrożeń, spośród których - z punktu widzenia interesującej nas problematyki - dwa wydają się szczególnie znaczące.

Pierwszym z nich jest tzw. eklektyzm. Termin ten w większości przypadków przywołuje skojarzenia związane z dziedziną architektury i sztuki, gdzie stosowany był w odniesieniu do prób łączenia różnych stylów. O ile jednak na powyższym gruncie stosowanie rozwiązań o charakterze eklektycznym może pozostawać co najwyżej kwestią gustów i upodobań, o tyle w odniesieniu do nauk takich jak filozofia czy teologia eklektyzm staje się zjawiskiem ogromnie niebezpiecznym. Terminem tym opisujemy - jak wyjaśnia papież - „postawę kogoś, kto w swoich poszukiwaniach, w nauczaniu i w argumentacji, także w sferze teologii, ma zwyczaj posługiwać się izolowanymi ideami zaczerpniętymi z różnych filozofii, nie bacząc na ich spójność i systematyczne powiązanie, ani na kontekst historyczny"18. Dobrze znanym przykładem próby takiego niedozwolonego łączenia ze sobą wiary objawionej z nieodpowiednią, choć wpływową w swoim czasie filozofią, była teologia wyzwolenia, której przedstawiciele

w 1950 r. encyklice o błędach przeciwnych wierze katolickiej, Humani generis, stanął w obronie filozofii scholastycznej: „Jest to więc rzecz bardzo opłakania godna - pisał że filozofia w Kościele przyjęta i uznana, jest dziś dla niektórych przedmiotem pogardy i że zuchwale oskarża się ją, że jest przestarzała co do formy a racjonalistyczna w swoim procesie myśli". Humani generis 32.

${ }^{16}$ Zob. więcej na ten temat. S. Kamiński, Nauka i metoda, s. 317.

17 Fides et ratio 43.

18 Fides et ratio 86. 
w uprawianiu teologii w sposób bezkrytyczny - jak stwierdza Jan Paweł II - przyjęli szereg tez wywodzących się z marksizmu ${ }^{19}$.

Drugim zagrożeniem - ważnym w perspektywie stanowiącego przedmiot naszych rozważań problemu - jest nieświadome przejmowanie przez teologię sprzecznych z wiarą założeń filozoficznych, przyjętych wcześnie - wprost lub milcząco - na gruncie rozlicznych teorii pedagogicznych, psychologicznych, czy też socjologicznych. Każda z tych dziedzin zakłada bowiem z konieczności jakąś określoną metafizykę i jakąś antropologię, jakąś wizję świata i człowieka. Jeśli zatem komuś, kto zajmuje się teologią, wydaje się, że któraś z tych dziedzin zastąpi filozofię w roli służebnicy teologii, dając narzędzia racjonalizacji prawdy objawionej, to przyjmuje on tym samym niejako „w pakiecie” założenia metafizyczne i antropologiczne, które w dziedzinach tych, na gruncie poszczególnych teorii, wcześniej założono, a których być może sobie nie uświadamia lub też nawet nie rozumie. Przed taką właśnie niebezpieczną prawidłowością przestrzega Jan Paweł II, stwierdzając, że „jeżeli teolog nie chce posługiwać się filozofią, powstaje niebezpieczeństwo, że będzie uprawiał filozofię nieświadomie"20. O błąd taki szczególnie łatwo w klimacie, nad którym papież ubolewa, pisząc o „lekceważącej postawie wobec teologii spekulatywnej oraz pogardzie dla filozofii klasycznej"21.

Wydaje się, że z tego typu zjawiskiem spotkać się można w szczególności na gruncie teologii duchowości, tak chętnie i niefrasobliwie korzystającej niekiedy z osiągnięć psychologii. Sprzyja temu nonszalancka postawa niektórych autorów, którzy niejako programowo ignorując klasyczną filozofię, w uprawianiu teologii wydają się poprzestawać na odwoływaniu się do Pisma Świętego oraz interesującej ich literatury psychologicznej ${ }^{22}$. Brak pogłębionej refleksji antropologicznej i etycznej sprawia, że miejsce zdrowej chrześcijańskiej antropologii, opartej na Bożym Objawieniu i na fundamencie realistycznej metafizyki, zajmować

\footnotetext{
19 Fides et ratio 54.

${ }^{20}$ Fides et ratio 77.

${ }^{21}$ Fides et ratio 55.

${ }^{22}$ Zob. np. A. Grün, Pismo Święte w interpretacji psychologii głębi, tłum.
} B. Białecki, Kraków 1996. Zob. też. E. Drewermann, Tiefenpsychologie und Exegese, t. I-II, Olten 1984-1985. 
zaczyna antropologia naturalistyczna, jaką przyjmowali twórcy wiodących kierunków psychologicznych.

Powstaje w tym kontekście pytanie, czy w ogóle, a jeżeli tak, to na ile, możliwą byłaby adaptacja na potrzeby uprawiania teologii rozwiązań, które u samych swoich podstaw zakładają fałszywą koncepcję człowieka. Czy nie popełniony zostaje w przypadku takiej adaptacji właśnie ów wspomniany błąd eklektyzmu, przed którym przestrzega Jan Paweł II, a teolog - w jak najlepszej, być może, wierze - przyjmuje jako prawdziwe błędne wnioski, jakie wyciągnął z przyjętych nieświadomie, fałszywych przesłanek? Czy wreszcie sama teza o aksjologicznej neutralności ludzkich uczuć nie pozostaje wyrazem niebezpiecznego kompromisu pomiędzy ewangeliczną prawdą o człowieku, z którego wnętrza, „z serca ludzkiego pochodzą złe myśli, nierząd, kradzieże, zabójstwa, cudzołóstwa [...]"23, a głównym dogmatem psychologii jako nowej, świeckiej religii, w myśl którego nikogo za nic winić nie można, należy jedynie starać się zrozumieć ${ }^{24}$.

\section{BOGACTWO PRZEJAWÓW ŻYCIA UCZUCIOWEGO}

Innym czynnikiem wpływającym na fakt nieporozumień, z jakimi spotkać się można wokół kwestii oceny moralnej uczuć, jest bogactwo przejawów ludzkiego życia uczuciowego, któremu wyraz daje Katechizm, stwierdzając, że stanowią one „obszar przejściowy i zapewniają więź między życiem zmysłowym i życiem ducha" ${ }^{25}$. Konstatacja powyższa wskazuje na swoistą hierarchię zjawisk, z jaką mamy do czynienia w tej sferze ludzkiej osobowości, a tym samym na różnorodność przejawów życia emocjonalnego w człowieku. O różnorodności tej świadczyć może również sama wielość określeń, którymi zwykło się opisywać różne jego aspekty. Katechizm mówi zamiennie o „uczuciach”, „emocjach”, „dążeniach zmysłowych”, „poruszeniach wrażliwości”, „wyobrażeniach”, „odczuciach”, „doznaniach", „poruszeniach zmysłowych"26.

${ }^{23} \mathrm{Mk} 7,21$.

${ }^{24}$ Skutki społeczne i prawne funkcjonowania tego fałszywego „dogmatu” w interesujący sposób przedstawia Grzegorz Górny. Zob. G. Górny, Anioł Północy, Warszawa 2010, s. $23 \mathrm{nn}$.

${ }^{25}$ KKK 1764.

${ }^{26}$ KKK 1763-1770. 
Jest rzeczą charakterystyczną, że pytanie-prośba, w trakcie zajęć dydaktycznych, o przyporządkowanie uczuć do cielesnej bądź też duchowej strony ludzkiej natury, nastręcza zazwyczaj pewnych trudności i dzieli audytorium. Zasadniczo bowiem uczucia wydają się przynależeć do naszej cielesności i stanowić tę sferę doznań, którą człowiek dzieli ze światem zwierzęcym, na co - jak zauważa o. Jacek Woroniecki - wskazuje ów najczęściej używany polski termin „uczucie”. Stanowi on - jak wyjaśnia wybitny polski etyk - odpowiednik greckiego páthos oraz łacińskiego passio, które to terminy, z racji swej etymologii, wskazują na pewien proces fizjologiczny, dotyczący zmysłowej strony natury ludzkiej ${ }^{27}$. Proces ten jest szczególnie wyraźny w przypadku uczuć niższych, takich jak odczucie ciepła i zimna, sytości i głodu, doznań związanych ze sferą seksualną itp. Nie sposób jednak nie zgodzić się z faktem, że dzielimy ze światem zwierząt również tak wydawałoby się „ludzkie” uczucia, jak radość, smutek czy przygnębienie ${ }^{28}$.

Odrębną, specyficznie ludzką kategorię uczuć stanowić będą natomiast uczucia wyższe, powiązane wprost z życiem umysłowym człowieka. Możemy je uporządkować według klasycznego porządku prawdy, dobra i piękna, wyszczególniając odpowiednio: uczucia intelektualne związane z poznaniem prawdy, takie jak np. uczucie pewności czy wątpienia; uczucia etyczne, towarzyszące naszej postawie wobec dobra moralnego, jak poczucie obowiązku, odpowiedzialności czy sprawiedliwości; uczucia estetyczne, powstające w związku z kontemplacją piękna, jak uczucie zachwytu czy podziwu. Niektóre z uczuć wyższych, takie jak uczucie przyjaźni, miłości czy uczucia religijne, łączyć będą ze sobą wszystkie wymienione wyżej aspekty. Z życiem umysłowym człowieka mogą pozostawać w ścisłym związku także uczucia radości i smutku, nabierając wówczas charakteru uczuć specyficznie ludzkich ${ }^{29}$.

27 Zob. J. Woroniecki, Katolicka etyka wychowawcza, Lublin 1995, t. 1, s. 149.

28 To dlatego tak często mieć możemy do czynienia z przejawami antropomorfizowania zachowań zwierzęcych, wyrażającego się w stwierdzeniach, że one też „wiedzą" czy „rozumieją”. Zob. T. Dutkiewicz, Filozofia i życie w Chrystusie. Filozoficzne podstawy moralnego nauczania Kościoła, Pelplin 2012, s. 237-238.

${ }_{29}$ Zob. H. Bless, Zarys psychiatrii duszpasterskiej, tłum. L. Kaczmarek, Warszawa 1980, s. 25. 
Biorąc pod uwagę przedstawioną powyżej różnorodność ludzkich uczuć, wydaje się rzeczą oczywistą, że zarówno stwierdzenie, w myśl którego wszystkie z wymienionych przejawów życia uczuciowego człowieka miałyby podlegać ocenie moralnej, jak i twierdzenie przeciwstawne, wyłączające je wszystkie poza ramy moralności, muszą być twierdzeniami fałszywymi. Ogólna zasada określająca tzw. przedmiot materialny etyki, jakim jest moralność, wskazuje na zbiór szeroko pojętych ludzkich aktów, którym przypisać można kwalifikację dobrowolności ${ }^{30}$. Pojęcie dobrowolności mieści w sobie w tym wypadku dwie składowe, jakimi są świadomość i wolność, które odnieść można zarówno do ludzkich działań, jak i aktów wewnętrznych, a więc myśli, pożądań, zamiarów czy uczuć. Stąd przywołane już we wstępie katechizmowe stwierdzenie, w myśl którego uczucia nabierają wartości moralnej w takiej mierze, w jakiej zależą od rozumu i woli.

Św. Tomaszowi z Akwinu zawdzięczamy cytowaną w Katechizmie, przytoczoną już również, definicję uczuć dobrowolnych, w której Akwinata zwraca uwagę na, rozstrzygający z punktu widzenia dobrowolności uczuć oraz naszej za nie odpowiedzialności, związek pomiędzy uczuciem a wolą podmiotu ${ }^{31}$. Zawdzięczamy mu także, bardzo istotne z punktu widzenia ustalenia zależności uczuć od rozumu i woli, wyróżnienie dwóch kategorii uczuć - cielesnych oraz zmysłowych ${ }^{32}$.

Kryterium powyższego podziału stanowi kolejność, w jakiej w strukturze danego uczucia pojawiają się jego elementy składowe. Jeżeli uczucie zapoczątkowane zostaje przez pewną przemianę fizjologiczną zachodzącą w ludzkim organizmie, która wtórnie dopiero pociąga za sobą odczucie przyjemności bądź też przykrości, wówczas uczucie takie zakwalifikować należy jako cielesne. Jeśli natomiast kolejność jest odwrotna,

${ }^{30}$ Zob. T. Ślipko, Zarys etyki ogólnej, Kraków 2002, s. 25 nn.

31 „Uczucia nazywane są dobrowolnymi albo dlatego, że nakazuje je wola, albo dlatego, że ich nie zabrania”. KKK 1767.

32 Św. Tomasz szczegółowo analizuje to zagadnienie w swych Kwestiach dyskutowanych o prawdzie w kontekście rozważań antropologicznych, dotyczących doznań duszy połączonej z ciałem, w Sumie Teologicznej natomiast, jedynie mimochodem o nim wspomina. Można przypuszczać, że fakt, iż rozważań tych nie włączył on do swojego pomnikowego dzieła, sprawił, że długo nie zwróciło ono na siebie należnej uwagi moralistów. Zob. T. Dutkiewicz, Filozofia i życie w Chrystusie, s. 252. 
tzn. tym, co decyduje o powstaniu uczucia jest czynnik poznawczy, np. postrzeżenie przedmiotu przy pomocy zmysłów zewnętrznych (wzroku, smaku, słuchu, dotyku, węchu), bądź też przedstawieniem go sobie przy pomocy zmysłów wewnętrznych (pamięci, wyobraźni), dalszą dopiero konsekwencją jest proces fizjologiczny oraz towarzyszące mu uczucie zadowolenia lub przykrości, mamy do czynienia z uczuciem przez św. Tomasza kwalifikowanym jako zmysłowe ${ }^{33}$.

Do kategorii uczuć cielesnych odnieść można w sposób zasadny tytułową tezę o neutralności aksjologicznej uczuć, jako że ich przyczynę stanowią procesy dokonujące się w ludzkim organizmie w sposób mimowolny („gęsia skórka” jako reakcja na zimno, zjawiska związane $\mathrm{z}$ trawieniem pokarmu, niektóre odruchy związane z życiem płciowym człowieka) ${ }^{34}$. O odpowiedzialności za nie można by mówić jedynie w sytuacjach, w których podmiot, odpowiednio przewidując następstwa, mógłby te zjawiska świadomie wywołać lub też ich uniknąć.

Wartości aksjologicznej nabierają natomiast uczucia zmysłowe, które przez fakt ich zakorzenienia w spełnianych przez człowieka funkcjach poznawczych, zostają w pewien sposób „uduchowione” i - jako takie - do pewnego przynajmniej stopnia podlegają działaniu władz rozumu i woli. Na szczególną uwagę w ocenie moralnej zasługuje również charakterystyczne zjawisko, polegające na przechodzeniu uczuć cielesnych w zmysłowe. Występuje ono wówczas, gdy sam początek całego procesu sięga mimowolnej przemiany organicznej, niosącej ze sobą odczucie przyjemności, bądź też przykrości, która to przemiana powoduje z kolei dobrowolne podjęcie określonej gry wyobraźni, przyczyniającej się do podtrzymania lub wzmożenia początkowej reakcji fizjologicznej ${ }^{35}$.

${ }_{33}$ Zob. Tomasz z Akwinu, Kwestie dyskutowane o prawdzie, 26, 2. Zob. też: M. A. Krąpiec, Psychologia racjonalna, Lublin 1996, s. 115.

${ }^{34}$ J. Woroniecki, Katolicka etyka wychowawcza, s. 154.

35 O. Woroniecki przedstawia powyższe zjawisko następująco: „W ten sposób odczuty głód lub pragnienie (uczucie cielesne) wzbudza w wyobraźni przedstawienie smacznego jadła lub napoju, i jego pożądanie utrzymuje w kręgu świadomości proces fizjologiczny głodu i przetwarza go w apetyt na jadło lub napój. O wiele dobitniej można to zauważyć w dziedzinie płciowej, gdzie w pierwszej fazie uczucia cielesnego żadnego wyobrażenia innej osoby nie ma; pojawia się ona dopiero wtedy, gdy w podnieconej wyobraźni zarysowuje się jakiś obraz, który staje się przedmiotem pożądania i przez to 
Warto podkreślić, że dla św. Tomasza z Akwinu wartość moralna uczuć zależnych od ludzkiego intelektu i woli pozostaje czymś bardziej jeszcze oczywistym aniżeli dobrowolność i wartość moralna podejmowanych przez człowieka działań zewnętrznych. Wynika to z faktu, iż - jak wyjaśnia Akwinata - „pożądanie zmysłowe jest bliższe samemu rozumowi i woli, niż zewnętrzne członki ciała, których poruszenia i czynności są przecież moralnie dobre lub złe w zależności od tego czy są dobrowolne. Tym bardziej więc uczucia, o ile są dobrowolne, trzeba uznać je za dobre względnie złe pod względem moralnym" ${ }^{36}$.

Wydaje się, że w świetle powyższych konstatacji, tezą, w myśl której uczucia ocenie moralnej nie podlegają, należałoby posługiwać się niezmiernie ostrożnie i powściągliwie, wprowadzając szereg zastrzeżeń i dodatkowych wyjaśnień, dotyczących m.in. różnorodności przejawów życia uczuciowego, posługując się najlepiej w kontekście tym nie terminem „uczucia”, jako nazbyt szerokim (co sprawia, że teza staje się fałszywa), ale mówiąc o „odczuciach”, jako niezależnych od ludzkiej woli, ledwo co uświadomionych, organicznych reakcjach na bodźce, pociągających za sobą przykre lub przyjemne doznanie ${ }^{37}$.

\section{PODSUMOWANIE}

Teza o rzekomej neutralności moralnej uczuć pojawia się w ostatnim czasie stosunkowo często, zarówno na poziomie przepowiadania, jak

podtrzymuje lub nawet wzmaga poruszenia fizjologiczne”. J. Woroniecki, Katolicka etyka wychowawcza, s. 155.

36 Tomasz z Akwinu, Suma Teologiczna, I-II, 24, 1.

37 Przykładem takiej ostrożności może być sposób, w jaki kwestię tę podejmuje np. autor opracowań, do których odwołuje się formacja w ramach katolickiego stowarzyszenia „Spotkania Małżeńskie”, J. Grzybowski, który - zawężając rozumienie terminu - pisze: „Uczucia są pierwszymi spontanicznymi, wewnętrznymi reakcjami na wydarzenia, sytuacje, w jakich się znajdujemy. Wyrażają stan psychiczny wobec aktualnych bodźców. [...] Uczucia w chwili pojawienia się nie są więc moralnie dobre, ani złe. Po prostu są". Wydaje się jednak, że w narracji autora przeoczony zostaje tym samym pewien istotny etap - w dalszym ciągu rozgrywający się w sferze uczuciowej człowieka - pomiędzy niezależnym od woli odczuciem a zachowaniem, postawą, decyzjami, do których w swoich dalszych konsekwencjach ono prowadzi. Zob. J. Grzybowski, Nieporadnik małżeński, Częstochowa 2013, s. 199. 
i w niektórych publikacjach podejmujących problematykę formacyjną. Z pewnym zdziwieniem odnotować można fakt, że celem jej uprawomocnienia przywoływane są niekiedy takie autorytety, jak św. Tomasz z Akwinu czy Katechizm Kościoła Katolickiego. Zarówno bowiem w nauczaniu Akwinaty, jak i w poświęconym moralności uczuć artykule Katechizmu, znajdujemy wskazanie na fakt istnienia uczuć, które pozostają zależne od ludzkiej woli, a tym samym podlegają ocenie moralnej.

Twierdzenie, w myśl którego do uczuć nie należy odnosić kwalifikacji dobra i zła, ograniczając się jedynie do konstatacji dotyczącej przyjemności, bądź też przykrości z nimi związanej, pozostaje zatem klasycznym przykładem półprawdy, która pretendując do bycia prawdą, staje się tym samym fałszem.

Wskazując na antropologiczno-etyczne uwarunkowania powyższego nieporozumienia, zwróciliśmy uwagę na dwie - jak się wydaje zasadnicze jego przyczyny.

Pierwsza $\mathrm{z}$ nich związana jest z faktem, że część teologów, odrzuciwszy jako narzędzie racjonalizacji prawdy objawionej realistyczną filozofię, sięgnęła do narzędzi wypracowanych na gruncie psychologii, przyjmując tym samym antropologiczne założenia sprzeczne $\mathrm{z}$ wiarą chrześcijańską. Widziana $\mathrm{z}$ tej perspektywy teza o neutralności aksjologicznej uczuć wydaje się być skutkiem próby eklektycznego łączenia sprzecznych ze sobą wizji człowieka i jego podmiotowości.

Druga z przyczyn ma charakter zasadniczo odmienny i wiąże się $\mathrm{z}$ bogactwem przejawów ludzkiego życia emocjonalnego. Zważywszy fakt, że uczucia, w myśl katechizmowego sformułowania, „zapewniają więź między życiem zmysłowym a życiem ducha”, nietrudno wskazać na ich różnorodność, wyrażającą się m.in. w tym, że niektóre z nich pojawiają się jako całkowicie niezależne o rozumu i woli, nie wchodząc tym samym - na początkowym przynajmniej etapie - w skład życia moralnego; inne zaś, ze względu na swoją zależność od rozumu i woli, mogą być oceniane jako moralnie dobre lub złe. $Z$ tej perspektywy analizowana tytułowa teza wydaje się być skutkiem braku metodologicznej precyzji i nieuprawnionego orzekania o całości tego, co prawdą pozostaje jedynie wyłącznie w odniesieniu do części. 


\section{BIBLIOGRAFIA}

Benedykt XVI, Jedność myśli i ducha Jana Pawła II, w: Jan Paweł II - mój umiłowany poprzednik, tłum. R. Łobko, Częstochowa 2007, s. 20-21.

Bless, H., Zarys psychiatrii duszpasterskiej, tłum. L. Kaczmarek, Warszawa 1980.

Drewermann, E., Tiefenpsychologie und Exegese, t. I-II, Olten.

Dutkiewicz, T., Filozofia i życie w Chrystusie. Filozoficzne podstawy moralnego nauczania Kościoła, Pelplin 2012.

Górny, G., Anioł Północy, Warszawa 2010.

Grün, A., Pismo Święte w interpretacji psychologii głębi, tłum. B. Białecki, Kraków 1996. Grzybowski, J., Nieporadnik małżeński, Częstochowa 2013.

Grzywocz, K., Uczucia niekochane, Kraków 2008.

Jan Paweł II, Fides et ratio, AAS 91 (1999), s. 5-88.

Kamiński, S., Nauka i metoda. Pojęcie nauki i klasyfikacja nauk, Lublin 1992.

Krąpiec, M.A., Psychologia racjonalna, Lublin 1996.

Leon XIII, Aeterni Patris, ASS 12 (1879), s. 97-115.

Moskal, P., Diakonia prawdy i „ancilla theologiae”, w: red. A. Maryniarczyk, Rozum otwarty na wiare, Lublin 2000, s. 107-112.

Pius XII, Humani generis, AAS 42 (1950), s. 561-578.

Ślipko, T., Zarys etyki ogólnej, Kraków 2002.

Tomasz z Akwinu, Kwestie dyskutowane o prawdzie, tłum. A. Aduszkiewicz, L. Kuczyński, J. Ruszczyński, t. 1-2, Kęty 1998.

Tomasz z Akwinu, Suma Teologiczna, tłum. F.W. Bednarski, S. Bełch, A. Głażewski, R. Kostecki, S. Piotrowicz, t. 1-35, Londyn 1962-1998.

Wasiukiewicz, A., Niebezpieczna psychologia, Poznań 2017.

Woroniecki, J., Katolicka etyka wychowawcza, t. 1-2, Lublin 1995. 